OPEN ACCESS

Vol. 7, No. 1, April, 2019

Page. $1-43$

DOI: https://doi.org/10.21107/jaffa.v7i1.6146
JOURNAL OF AUDITING, FINANCE, AND FORENSIC ACCOUNTING (JAFFA)

E-ISSN: 2461-0607 ISSN: 2339-2886

https://journal.trunojoyo.ac.id/jaffa/index

\title{
EFFECTS OF TIME BUDGET PRESSURE, AUDIT FEE, INDEPENDENCE AND COMPETENCE ON AUDIT QUALITY
}

Gevi Kurniawan; Sutjipto Ngumar; Kurnia

Accounting Department, STIESIA Surabaya

Article Info:

Received: 5 Juli 2019

in revised form: 19 Juli 2019

Accepted: 21 November 2019

Available Online: 19 December 2019

\section{Keywords:}

Audit Quality, Time Pressure, Audit Fee, Independence,

Competence

Corresponding Author:

Email: kurniawangevi@gmail.com

\begin{abstract}
This study aims to examine the determinants of audit quality, which employs a quantitative method by conducting a survey on 98 public accountants in East Java across of 58 public accounting companies. The findings indicate that audit fee, independence and competence affect audit quality. However, there is no effect of time budget pressure on audit quality, which indicates that the auditors have tendency to maintain audit quality even under time budget pressure.
\end{abstract}

Abstrak; Penelitian ini bertujuan untuk menguji pengaruh faktor-faktor yang berpengaruh terhadap kualitas audit. Penelitian ini menggunakan metode kuantitatif dengan Teknik survey pada 98 akuntansi public di Jawa Timur dari 58 Kantor Akuntan Publik. Hasil penelitian menunjukkan bahwa audit fee, independensi dan kompetensi berpengaruh terhadap kualitas audit. Sementara, tekanan waktu tidak berpengaruh terhadap kualitas audit. Hal tersebut mengindikasikan bahwa auditor cenderung mempertahankan kualitas audit meskipun berada pada kondisi tekanan waktu. 


\section{INTRODUCTION}

Audit quality is an indicator of the quality of information produced by an independent auditor (Mulyadi, 2002: 4). A quality audit allows the auditor to find and reveal errors or violations in financial statements (Restiyani, 2014). High quality audit produces financial statements reflecting the real condition without any misstatement or fraud. In fact, auditor as an independent institution has failed to bridge the gap of interest between agents and principle. In addition, there are many cases involving public accounting companies in Indonesia from PMW public accountants to KAP MW and Partners which lead to suspension of the public accountants' permits for 2 years by the Minister of Finance, Sri Mulyani since March 15, 2007. The second case is SNP Finance. Released from CNBC media on Thursday (30/8/2018).

The violations of the public accountant offices were triggered by the high competition among public accounting companies. They compete by reducing the service fee and audit time; hence, the audit process is faster. This opinion is supported by (Kurniasih, 2014) who explains that audit fee and tenure audit variables have significant effects on audit quality. This is due to pressure of price during the engagement process by public accounting company with its clients who request fast audit time for tender purpose and account for the shareholders. The result of research (Chrisdinawidanty, et al. 2016) proves that audit fee has a positive and significant effect on audit quality. It means that the higher the auditor's audit fee, the higher the quality, while the lower the audit fee, the worse the quality.

Various cases and violations involved the public accounting companies indicate that the quality of audit, particularly in developing countries, such as in Indonesia, show that there are many intentional and intentional frauds occur. However, it does not mean that all public accountants conduct the same violations. In nutshell, the researcher expects to test the quality of public accounting in East Java. East Java is chosen because it is the second largest public accounting centers in Indonesia after Special Capital Region of Jakarta (Directory IAPI, 2018).

IAPI as a forum for public accounting companies, set the guidelines for assessing audit quality. Based on IAPI circular number 0999/X/IAPI/2016 there are 8 (eight) quality indicators to improve the quality of auditor, including: auditor competency, ethics and independence, time use of key engagement personnel, engagement quality, quality result or external and internal party inspections, engagement controls, organization and governance of KAP and service fee policy. Based on the summary above, this research examines audit quality using several IAPI quality indicators combined with the occuring cases in public accounting companies that are time budget pressure, audit fee, independence and competence.

\section{LITERATURE REVIEW AND HYPOTHESES DEVELOPMENT}

Time budget is an estimated time by the audit manager to perform an audit program. Time budget setting has several goals including as an efficient method for developing staff schedule, as an important guide for different audit areas, as a stimulus for auditor staff and to obtain efficient performance as a tool for determining invoice for clients (Ivancevich, 2005). Similar to Hill (2005), McGuy, et al. (1990) states that time budget has a number of benefits if it is used appropriately such as: as an efficient method for scheduling staff, providing guidance on the various audit areas, giving incentives to audit staff to work efficiently and act as a tool for determining audit fees. When the auditor is confronted with a high level of work while the given time budget is lower, the auditor tends to perform audit quality reduction such as reducing the samples, does not conduct a good procedure and accept doubful client explaination. Pramudianti (2016) explains that time budget pressure is used to measure the auditor efficiency in completing their work. This process indicates that time budget pressure has a negative effect on audit quality and indicates that the higher time budget pressure experienced by an auditor, the worse the audit quality, and therefore it will lead to reduction in audit procedures by the auditor (Pramudianti, 2016; Ningsih \& Yaniartha, 
2013). Therefore, the proposed hypothesis is: H1: Time budget pressure negatively affects audit quality.

Pratistha and Widhiyani (2014) state that auditor with high fees will conduct more extensive and in-depth audits, so the possible irregularities in the client's financial statements can be detected. The study indicates that amount of audit fee has a positive and significant effect on the audit quality. Further, studies by (Ettredge et al. 2014), (Salehi, et al. 2017), supported by (Kurniasih, 2014), (Chrisdinawidanty, et al. 2016) and (Lestari, 2017) indicate that audit fees have a positive and significant effect on the audit quality. If there is a decline in audit fees, the audit quality will decrease as well. Therefore, the proposed hypothesis is: H2: Audit fee positively affects audit quality.

Independence is the mental attitude of a public accountant of not being easily influenced by other parties in conducting their duties (Agusti and Pertiwi, 2013). Independence can be proxied into four sub-variables. The first is long relationship with the client (audit tenure), where the Indonesian government limits the auditor's tenure to a maximum of 3 years for the same client, while for public accounting companies (KAP) up to 5 years. This process aims to keep the gap between the auditor and the client in order to prevent accounting scandals. Pratistha and Widhiyani (2014) state that the auditor's independence is demonstrated when conducting their duties and obligations. It reflects a fair and independent auditor, so, the report is reliable. If the public accountant is not independence, it will affect on the poor audit quality. So, the audit report does not match the reality and cannot be used as a basis for decision making. Research by (Pratistha and Widhiyani, 2014) indicates that auditor independence has a positive and significant effect on audit quality. Several studies demonstrated that independence has a positive and significant effect on audit quality (Futri and Juliarsa, 2014; Lestari, 2017; RG and Parlindungan, 2017; Agusti and Pertiwi, 2013; Wiratama and Budiartha, 2015; Ardini, 2010; Ningsih and Yaniartha, 2013 ; Carolita, 2012; Gunawan, 2012; Pratistha and Widhiyani, 2014). So, the higher the independence level, the better the result. Therefore, the proposed hypothesis is: H3: Independence positively affects the audit quality.

Competence in audit is knowledge, expertise, and experience required by auditors to conduct their job objectively, carefully and thoroughly (Tarigan and Susanti 2013). Furthermore, (Lestari, 2017) the auditor's expertise will affect the quality of the result because the more participation in trainings, seminars and certificates, the more capable they will be. So, it is expected that they can conduct their duties and use their special skills in detecting errors to increase correct explanations in analytical procedures. Ningsih and Yaniartha (2013) state that the higher education of an auditor, the wider the knowledge he has. In addition, a lot of experience will make it easier for the auditors to detect errors that occur in conducting audits. Therefore, auditor competence as seen from knowledge and experience can affect audit quality. Researches by (Ilmiyati and Suhardjo, 2012), (Carolita, 2012), (Gunawan, 2012), (Rahmawati, 2013), state that auditor competence has a positive and significant effect on audit quality; so, the higher the competence, the better the quality. Therefore, the proposed hypothesis is: H4: Competence positively affects the audit quality.

\section{RESEARCH METHODOLOGY}

This reseach is a quantitative study by using multiple regression analysis. Prior to the regression test, the classical assumption test were conducted in the form of normality, autocorrelation, multicollinearity, and heteroscedasticity tests. The population of this study was all auditors who work at public accounting companies, throughout East Java region. The sample was selected by purposive sampling which resulted in senior auditors or supervisors. In addition, the researcher used these criteria because they have extensive working hours as well as audit experience. The data type in this research was a primary data using questionnaire method. It consisted of two sections: section A contained questions about personal information of the respondents, while section $B$ contained questions about the elaboration of dependent and independent variables using likert scale.

The variable in this research was independent and dependent variable. The independent variables were time budget pressure, audit fee, independence and 
competence, while the dependent variable was audit quality. Audit quality was measured by using several indicators. The first was audit quality and second was audit compliance with the standard. Time budget pressure was measured by several indicators. The first was audit time allocation, the second was the suitability with management risk, the third was time budget pressure from client, the fourth premature sign off, the fifth effectiveness and efficiency, the sixth completion of audit procedures with the budget time, seventh completion of audit procedures with time budget as a constraint.

Audit fee measurement was conducted through several indicators, the first was management risk, the second was the audit work provided, the third was level of expertise in the task, the fourth was audit fee with management risk, the fifth was IAPI management fee indicators by Law Number 2 of 2016, and the sixth was cost structure of the relevant accounting company. Independence measurement was a mental attitude free from influence, not controlled by other parties, and not depend on others (R.G and Parlindungan, 2017). Independence was measured by several indicators, the first was the length of relationship, the second was pressure from client, the third was review of peer auditors and the fourth was non-audit service. Finally, competency measurement used several indicators, the first was understanding knowledge on the basis of relevant standards (SAK and SPAP, training attended by auditor, and audit experience).

\section{FINDINGS AND DISCUSSION}

Based on the analysis, the feasible data is 98 (84.5\%) from 116 questionnaires answered by the respondents. The respondents' demographic distribution can be seen in the following table:

Table 1. Demographic of Respondents

\begin{tabular}{lccc}
\hline \multicolumn{1}{c}{ Description } & Total & Male & Female \\
\hline Supervisor & 6 & 4 & 2 \\
\hline Senior Auditor & 92 & 76 & 16 \\
\hline Junior auditor & 2 & 2 & 0 \\
\hline Feasible questionnaire & 100 & 82 & 18 \\
\hline
\end{tabular}

\section{Classic Asumption Test}

Normality test using Kolmogorov-Smirnov test indicates a significance value greater than 0.05 , which means the data in this study is normal. Multicollinearity can be seen from VIF and tolerance value. If VIF is lower than 10 and the tolerance is higher than 0.1 , the data is free from multicollinearity problem. The test result on research variables indicates, VIF is less than 10 and the tolerance value is higher than 0.1 , so, the data is free of multicollinearity. Heteroscedasticity was tested using glacier test. If the significance value is greater than 0.05 , the data is free from heteroscedasticity issue. The test result indicates that significance value is greater than 0.05 , so, the data is free of heteroscedasticity. 


\section{Hypothesis Test}

The result of linear regression test among the independent variables in the form of time budget pressure, audit fee, independence and competence on dependent variable in the form of audit quality, can be seen in table 2 as follows.

Table 2 Hypothesis Test

\begin{tabular}{|c|c|c|c|c|c|}
\hline \multicolumn{6}{|c|}{ Coefficients $^{a}$} \\
\hline \multirow[b]{2}{*}{ Model } & \multicolumn{2}{|c|}{$\begin{array}{c}\text { Unstandardized } \\
\text { Coefficients }\end{array}$} & \multirow{2}{*}{$\begin{array}{c}\text { Standardized } \\
\text { Coefficients } \\
\text { Beta }\end{array}$} & \multirow[b]{2}{*}{$\mathrm{t}$} & \multirow[b]{2}{*}{ Sig. } \\
\hline & $\mathrm{B}$ & $\begin{array}{l}\text { Std. } \\
\text { Error }\end{array}$ & & & \\
\hline $\begin{array}{ll}1 & \text { (Constant) }\end{array}$ & $-4,114$ & 3,592 & & $-1,145$ & 0,255 \\
\hline $\begin{array}{l}\text { Time Budget } \\
\text { Pressure }\end{array}$ & 0,108 & 0,093 & 0,117 & 1,160 & 0,249 \\
\hline Audit Fee & 0,345 & 0,129 & 0,264 & 2,673 & 0,009 \\
\hline Independence & 0,237 & 0,087 & 0,283 & 2,717 & 0,008 \\
\hline Competence & 0,452 & 0,178 & 0,252 & 2,541 & 0,013 \\
\hline
\end{tabular}

\section{Effects of Time Budget Pressure on Audit Quality}

Findings of this study indicate that time budget pressure has no effect on audit quality. It does not support the study of McGuy, Alderman, and Winter (1990) indicating time budget which is used properly may result in a number of benefits, for instance, producing an efficient method for staff schedule, providing guidance on the relative interest of various audit fields, providing incentives to audit staff to work efficiently, and acting as a tool to determine audit fees. However, studies of Pramudianti (2016) and Ningsih; and Yaniartha (2013) found that time budget pressure has a negative effect on audit quality.

Time budget pressure does not affect audit quality; it means that auditor in conducting his audit, despite the time budget pressure or time reduction, it will not affect the quality audit. This finding supports previous researches i.e. Pikirang et al (2017): Rizal and Liyundira (2016). It indicates that the auditor is maintaining his company reputation. Accordingly, Rustiarini (2013), Noviansyah \& Liyundira (2016), Putri (2013) suggested that the auditor has adjusted time allocation to the task complexity; hence, he must finish the tasks efficiently.

Time budget pressure does not affect audit quality, which means that Public Accounting Company maintains good reputation and its entity as well as avoid sanctions in accordance with Law Number 5 of 2011 on Public Accountants. Given time allocation to the auditor is categorized as realistic and adequate. In addition, an auditor has used and adjusted his time in accordance with the agreement, so that the time budget pressure encountered by an auditor does not have any effect on quality (Lestari, 2017). This result is in accordance with Mulyadi's research (2017) in which audit time budget pressure does not affect audit quality since audit time budget pressure is normal for an auditor, so he will be more careful in distributing sub-activities to the team members for an effective and timely audit.

\section{Effects of Audit Fee on Audit Quality}

Test result indicates that audit fee affects audit quality. It means that the higher audit fees, the higher quality provided by the auditor. This statement supports Pratistha and Widhiyani (2014) in which auditors with high fees will conduct a more extensive and in-depth audit. Consequently, any possibility of financial irregularities in client's financial statements can be detected. The result is also supported by Lestari (2017), stating that auditors with high fees will have more responsibility in conducting the tasks from the clients.

This finding is in aggrement with Ahmad's research (2010) suggested that before the auditor conduct the task, the public accounting company negotiates with client's management regarding the fee for the work. The public accounting management 
consider the auditors' level of expertise, complexity, and risks, so, they can provide a good quality audit.

Higher audit costs will improve audit quality. It is because a one-year-audit fee and the estimated operating costs can improve audit quality (Andriani and Nursiam, 2017). The same point is urged by Arisinta (2013) that the higher audit fee, the higher quality audit can be obtained compared to lower audit fee. Incentives are provided in order to keep clients from using other auditors, since losing clients means losing income in the future. Finally, auditors may experience price pressure from the clients which then affects the audit quality. Rational managers will not choose high-quality auditors and pay more money if the characteristics of the company are poor.

\section{Effects of Independence on Audit Quality}

One of results of this study indicates that independence affects audit quality. The finding is in line with Pratistha and Widhiyani (2014) in which the independence demonstrated by the auditor when performing duties reflects that he is fair and free of any influence, and therefore the report is reliable. The loss of independence will give an effect on poor quality as suggested by Gunawan (2012) that independence significantly affects audit quality. This research explains that the auditor's independence will hinder the client to influence him; and hence, the audit process will be conducted transparently, and thus improving the audit quality. Moreover, independence indicates that an auditor should have no personal interest as well. The auditor always conducts the fair procedures as an independent party. Pratistha and Widhiyani (2014) explain that independence reflects a fair auditor who is free of any influence. If an auditor loses his independence, it will affect the quality and lead to hesitation in decision-making. Therefore, the auditor is required to integrate an independence in conducting his job to produce a good quality of an audit. Consequently, the public accountants will be trusted by users of financial statements regarding management assertion (Ardini, 2010).

\section{Effects of Competence on Audit Quality}

Another result of this study indicates that competence affects audit quality, which supports Lestari (2017) stating that an auditor's expertise will affect audit quality, which mean the more participation in trainings, seminars, and certificates, the more capable they will conduct their duties. Furthermore, special experiences in detecting errors will increase public accountants in providing a correct explanation in an analytical procedure. Accordingly, Ningsih and Yaniartha (2013) urged that the higher the education level, the wider the knowledge possessed by the auditor. In addition, a lot of experience will make the auditors easier in detecting errors in audit process. Therefore, auditor's competence can be seen from knowledge and experience can affect audit quality.

Auditor's competence can be formed through knowledge and experience. So, the higher the competency level, the higher the audit quality. In addition, to conduct audit tasks, auditors need the knowledge on audit, accounting, and client's industry. In audit process, auditors must act as an expert in accounting and auditing. In order to obtain the expertise, it can be started from a formal education, then improving through audit experiences and practices. The more experienced an auditor, the more sensitive he is with the financial statements' errors (Arisinta, 2013).

\section{CONCLUSIONS AND SUGGESTIONS}

Based on the analysis, it can be concluded that: Time budget pressure has no effect on audit quality because auditor tries to maintain the audit quality instead of reducing the audit procedures. The auditor has adequate time in conducting his duties to complete the given tasks; so, he must utilize the time efficiently. Audit fee affects audit quality, where the auditors with high fees will conduct more extensive and in-depth audits to detect irregularities. High audit fee will require higher responsibility for the auditor in conducting his duties.

Independence affects audit quality. Independence is indicated by the auditor's attitude in conducting the duties, which is reflected by the fair attitude, free of any 
influence; so, the financial statements will be reliable. Also, the independence means that the auditors free from any personal interest, including the client's interests. Hence, the audit process will be conducted transparently to improve audit quality. Moreover, competence affects audit quality. When an auditor is actively participating in trainings and seminars, he will obtain more certificates and expected to be more capable in conducting his duties. Special experience is also needed in detecting errors in financial statements and providing a correct explanation in an analytical procedure.

Based on the conclusion, suggestions for the future studies are to develop other variables that affect audit quality such as audit rotation, audit tenure, review procedure, quality control, education level, professional ethic, experience, and so forth.

\section{REFERENCES}

Agusti dan Pertiwi. 2013. Pengaruh Kompetensi, Independensi Dan Profesionalisme Terhadap Kualitas Audit (Studi Empiris Pada Kantor Akuntan Publik Se Sumatera). Jurnal Ekonomi 21(3).

Ahmad. 2010. Pengaruh Fee Audit, Tekanan Anggaran, Waktu Audit terhadap Kualitas Audit (Penelitian pada Kantor Akuntan Publik di Wilayah Kota Bandung yang terdaftar di IAPI). Jurnal Akuntansi. 1 (1): h-16.

Andriani, Ninik and, Nursiam. 2017. Pengaruh Fee Audit, Audit Tenure, Rotasi Audit dan Reputasi Auditor terhadap Kualitas Audit (Studi Empiris Pada Perusahaan Manufaktur yang Terdaftar di Bursa Efek Indonesia Tahun 2013-2015). Skripsi Tesis. Dapat diakses di http://eprints.ums.ac.id/54649/

Ardini, Lilis. 2010. "Pengaruh Kompetensi, Independensi, Akuntabilitas, dan Motivasi Terhadap Kualitas”. Majalah Ekonomi. No.3 Desember 2010. Hal 329-349.

Arisinta. 2013. Pengaruh Kompetensi, Independensi, Time Budget Pressure, Dan Audit Fee Terhadap Kualitas Audit Pada Kantor Akuntan Publik Di Surabaya. Jurnal Ekonomi dan Bisnis. Magister Akuntansi Fakultas Ekonomi dan Bisnis Universitas Airlangga.

Carolita. 2012. Pengaruh Pengalaman Kerja, Independensi, Objektifitas, Integritas, Kompetensi, dan Komitmen Organisasi Terhadap Kualitas Hasil Audit (Studi Pada Kantor Akuntan Publik Di Semarang). Skripsi.UNDIP.

Chrisdinawidanty, Z Nur, Hiro Tugiman, dan Muhamad Muslih. 2016. Pengaruh Etika Auditor Dan Fee Audit Terhadap Kualitas Audit (Studi Kasus Pada Kantor Akuntan Publik Di Wilayah Bandung). e-Proceeding of Management 3(3): 2355-9357.

CNBC media Indonesia. 2018. Kasus SNP Finance, Sri Mulyani Hukum Deloitte Indonesia.https://www.cnbcindonesia.com/market/20180830074647-17-

30904/kasus-snp-finance-sri-mulyani-hukum-deloitte-indonesia. 11 April 2018 (20.05).

Directory IAPI. 2018. Anggota Akuntan Publik IAPI. Januari. IAPI. Jakarta.

Ettredge, M., Fuerherm, E.E. and Li, C. 2014. Fee Pressure and Audit Quality. Accounting Organizations and Society, 39: 247-263

Futri dan Juliarsa. 2014. Pengaruh independensi, profesionalisme, tingkat pendidikan, etika profesi, pengalaman, dan kepuasan kerja auditor. E-Jurnal Akuntansi Universitas Udayana 8(1): 41-58.

Gunawan. 2012. Pengaruh Tingkat Independensi, Kompetensi, Obyektifitas, Dan Integritas Auditor Terhadap Kualitas Audit Yang Dihasilkan Kantor Akuntan Publik di Surabaya. Jurnal Ilmiah Mahasiswa Akuntansi.1(4).

Guy, D.M., Alderman., C.W., Winter dan Alan J. 1990. Auditing. 2 Edition. Harcourt Brace Jovanivich Publisher. 
Ilmiyati dan Suharjdo. 2012. Pengaruh Akuntabilitas dan kompetensi terhadap kualitas audit (Studi empiris pada Kantor akuntan Publik Semarang ) jurnal akuntansi:2301-9328

Institut Akuntan Publik Indonesia (IAPI). 2016. Indikator Pengukuran Kualitas Audit. Surat edaran IAPI nomor 0999/X/IAPI/2016. IAPI. Jakarta.

Ivancevich, John M., Robert Konopaske dan Michael T. Matteson. 2005. Organizational Behavior and Management, Seven Edition, New York: McGraw-Hill

Kurniasih, M. 2014. Pengaruh Fee Audit, Audit Tenure, dan Rotasi Audit Terhadap Kualitas Audit. Skripsi. Univesitas Diponegoro Semarang.

Lestari. 2017. Pengaruh Fee Audit, independensi, Kompetensi dan etika auditor Terhadap Kualitas Audit: Skripsi-Fakultas Ekonomi Dan Bisnis Islam -Institut Agama Islam Negeri Surakarta.

Mulyadi, 2002. Auditing, Buku Dua, Edisi Ke Enam, Penerbit: Salemba Empat, Jakarta.

Mulyadi, Faricha, C. Pratami. 2017. Pengaruh Kompetensi, Kompleksitas Tugas, dan Tekanan Waktu Terhadap Kualitas Audit dengan Etika Auditor sebagai Variabel Moderasi (Studi Empiris pada Auditor di BPKP Provinsi Lampung). Skripsi. Jurusan Akuntansi Fakultas Ekonomi dan Bisnis Universitas Lampung.

Ningsih dan Yaniartha. 2013. Pengaruh Kompetensi, Independensi, Dan Time Budget Pressure Terhadap Kualitas Audit. E-Jurnal Akuntansi Universitas Udayana 4(1) : 92- 109.

Noviansyah, Rizal, Liyundira, dan Fetri Setyo. 2016. Pengaruh Tekanan Waktu dan Independensi terhadap Kualitas Audit. Jurnal Ilmu Ekonomi. STIE Widya Gama Lumajang.

Pikirang Julita, Sabijono Harijanto, Wokas. 2017. Pengaruh Tekanan Waktu, Independensi dan Etika Auditor terhadap Kualitas Audit di Kantor Inspektorat Kabupaten KepulauancSangihe. Jurnal Going Concern: Jurnal Riset Akuntansi. Volume 12 Nomor 2. https://doi.org/10.32400/gc.12.2.18034.2017.

Pramudianti, Astri. 2016. Pengaruh Tekanan Anggaran Waktu, Prosedur Review, Kontrol Kualitas dan Karakteristik Personal Auditor terhadap Perilaku Pengurangan Kualitas Audit. Skripsi. https://eprints.uny.ac.id/38925/1/SKRIPSI\%20LENGKAP_ASTRI\%20PRAMUDIAN TI.pdf

Pratistha dan Widhiyani. 2014. Pengaruh Independensi Auditor Dan Besaran Fee Audit Terhadap Kualitas Proses Audit. E-Jurnal Akuntansi Universitas Udayana 6(3):419428.

R.G dan Parlindungan. 2017. Pengaruh Independensi Terhadap Kualitas Audit Dengan Prinsip Kehati-Hatian Sebagai Variabel Moderasi. Jurnal Akuntansi STIE MDP. Palembang.

Rahmawati, Januar Dwi Widya. 2013. Pengaruh Kompetensi dan Independensi Terhadap Kualitas Audit. Jurnal Ilmiah Mahasiswa Fakultas Ekonomi dan Bisnis Universitas Brawijaya Vol. 1, No.1: Semester Ganjil 2012/2013.

Restiyani. 2014. Pengaruh Pengalaman Auditor Dan Independensi Auditor Terhadap Kualitas Audit (Penelitian Pada Kantor Akuntan Publik Kota Bandung), Skripsi, Fakultas Ekonomi Universitas Widyatama, Bandung.

Rizal dan Liyundira. 2016. Pengaruh tekanan waktu dan independensi Terhadap kualitas audit (studi pada kantor akuntan publik di wilayah malang). Jurnal ilmu penelitian ekonomi WIGA. 6(1): 45-52.

Rustiarini, Ni Wayan. 2013. Pengaruh Kompleksitas Tugas, Tekanan Waktu, dan Sifat Kepribadian pada Kinerja. Jurnal Makara Seri Sosial Humaniora. Vol. 17 No. $2 \mathrm{Hal}$ 
126-138.

online.

http://hubsasia.ui.ac.id/old/index.php/hubsasia/article/view/2961.

Salehi, M., Jafarzadeh, A., and Nourbakhshhosseiny, Z. 2017. The Effect of Audit Fees Pressure on Audit Quality During The Sanctions in Iran. International Journal of Law and Management 59: 66-81.

Tarigan dan Susanti. 2013. Pengaruh Kompetensi, etika auditor dan fee audit Terhadap Kualitas Audit: Jurnal akuntansi.13(1).

Wiratama dan Budiartha. 2015. Pengaruh Independensi, Pengalaman Kerja, Due Professional Care Dan Akuntabilitas Terhadap Kualitas. E-jurnal Akuntansi Universitas Udayana 10(1): 91-106. 